\section{Estimation of Release Properties of Slow-release Fertilizer Materials}

\author{
L. Carolina Medina, Jerry B. Sartain, and Thomas A. Obreza ${ }^{1}$
}

ADDITIONAL INDEX WORDs. nitrogen, laboratory extraction method, soil incubation

SUMMARY. Slow-release fertilizers marketed to the public usually include a claim that nutrient release will last for a specific time period (e.g., 6, 9, or 12 months). However, no official laboratory method exists that can verify these claims. A long-term (180 days) incubation method has been developed that produces constants for an exponential model that characterizes nutrient release as a function of time. In addition, a relatively short-term $(74 \mathrm{~h})$ extraction method has been developed to assess nutrient release under accelerated laboratory conditions. Through regression techniques, release constants established for individual slow-release nutrient sources by the incubation method are used in conjunction with the laboratory extraction data to verify the release claims of slow-release fertilizers. Nutrient release for selected single materials has been predicted with greater than $90 \%$ accuracy in previous studies. Nutrient release from mixtures of slow-release products has been more variable. It is typical for water-soluble and slow-release fertilizers to be mixed in commercial products. Ultimately, it is intended that these methodologies will be accepted as an official method to verify nutrient release claims placed on slow-release fertilizers.

$\mathrm{N}$ utrient use efficiency, particularly for nitrogen $(\mathrm{N})$ fertilizer, is still low despite sig nificant improvements in crop production over the last few decades. Development of slow-release fertilizer (SRF) evolved as a potential way to enhance nutrient use efficiency while reducing detrimental effects on the environment. Although the use of SRF materials has almost doubled in the last 50 years, it represents only $0.15 \%$ of the global mineral fertilizer market. Most SRF products have been developed for use in specialty fertilizer markets (e.g., lawn care, golf courses, nurseries, landscaping) with an annual increase in demand of $5 \%$. The agricultural sector consumes only about $10 \%$ of the total SRF used, but demand has been increasing at an annual rate of $10 \%$ (Trenkel, 1997).

During the last few decades, several unique technologies have been developed to characterize the release properties of SRF materials. These technologies are product-specific based on the regulation and analysis of each material. However, with the constant introduction of new SRF products in specialty and nonspecialty markets, an individualized approach to

Soil and Water Science Department, University of Florida, 2169 McCarty Hall, P.O. Box 110290, Gainesville, FL 32611

${ }^{1}$ Corresponding author. E-mail: obreza@ufl.edu. regulation is inadequate to verify label claims and material performance. The use of several technologies to evaluate nutrient release properties also introduces consumer confusion regarding choices when purchasing SRF and lack of protection against ineffective products. Despite previous development of many technologies for characterizing SRF materials, no analysis methods have been accepted for use by the Association of Analytical Chemists International since 1970 (Sartain et al., 2004a). An approved methodology is needed to estimate nutrient release properties from a broad range of materials.

A SRF task force was established in 1994 by the Association of American Plant Food Control Officials to address issues regarding the effective regulation and analysis of SRF materials. To date, a soil incubation methodology and a short-term laboratory nutrient extraction method have been developed to overcome these regulatory issues. A statistical correlation between these two methods such that values from the laboratory extraction of SRFs can be used to predict the long-term release of nutrients is under study. The development and application of these methods are described here.

\section{Soil incubation methodology}

The soil column incubation technique described by Sartain et al. (2004a) was used to estimate $\mathrm{N}$ release with time. A surface layer $(0$ $5 \mathrm{~cm}$ depth) of Arredondo fine sand $(90 \mathrm{~g})$ (Loamy siliceous, hyperthermic, Grossarenic Paleudult) from central Florida was mixed with noncoated quartz sand $(1710 \mathrm{~g})$ and the equivalent of $450 \mathrm{mg} \mathrm{N}$ from each fertilizer source. The purpose of adding the field soil was to introduce the biotic component of a natural system. These mixtures were placed in $30-\mathrm{cm}$ long, 3-inch-diameter PVC incubation lysimeters. The sand/soil/ $\mathrm{N}$ source mixture was brought to $10 \%$ moisture by adding $180 \mathrm{~mL}$ of $0.01 \%$ citric acid solution. Citric acid was added to stabilize the $\mathrm{pH}$ of the mixture and to serve as a microbial energy source. A $50-\mathrm{mL}$ beaker containing $20 \mathrm{~mL}$ of $0.2 \mathrm{M}$ sulfuric acid was placed in the head space of the incubation lysimeter as an ammonia trap. This solution was replaced and analyzed for ammonium $\mathrm{N}\left(\mathrm{NH}_{4}-\mathrm{N}\right)$ by titration every $7 \mathrm{~d}$ to determine volatilized $\mathrm{N}$ during the incubation period. The soil columns were incubated at about $24^{\circ} \mathrm{C}$ in a glasshouse. Each lysimeter was leached after 7 , $14,28,42,56,84,112,140$, and 180 $\mathrm{d}$ after starting the incubation with one pore volume of $0.01 \%$ citric acid $(500 \mathrm{~mL})$ using a vacuum manifold for $2 \mathrm{~min}$. Leachate volume was recorded and an aliquot was frozen for later analysis of total $\mathrm{N}$ using an $\mathrm{N}$ analyzer (Antek 9000; PAC Co., Houston, TX). The weight of total $\mathrm{N}$ leached was determined by multiplying $\mathrm{N}$ concentration by leachate volume. Because no volatile ammonia was detected in the ammonia trap

\begin{tabular}{llll}
\hline $\begin{array}{l}\text { Units } \\
\text { To convert U.S. to SI, } \\
\text { multiply by }\end{array}$ & U.S. unit & SI unit & $\begin{array}{l}\text { To convert SI to U.S., } \\
\text { multiply by }\end{array}$ \\
\hline 29.5735 & $\mathrm{fl} \mathrm{oz}$ & $\mathrm{mL}$ & 0.0338 \\
2.54 & inch $(\mathrm{es})$ & $\mathrm{cm}$ & 0.3937 \\
28.3495 & $\mathrm{oz}$ & $\mathrm{g}$ & 0.0353 \\
28,350 & $\mathrm{Oz}$ & $\mathrm{mg}$ & $3.5274 \times 10^{-5}$ \\
$\left({ }^{\circ} \mathrm{F}-32\right) \div 1.8$ & ${ }^{\circ} \mathrm{F}$ & ${ }^{\circ} \mathrm{C}$ & $\left(1.8 \times{ }^{\circ} \mathrm{C}\right)+32$
\end{tabular}


during any of the incubation periods, the weight of $\mathrm{N}$ recovered in the leachate at the various sampling intervals was used as an estimate of the total $\mathrm{N}$ released with time.

Twenty-four lysimeters (six treatments $\times$ four replications) were arranged in a randomized complete block design. The percentage of the $\mathrm{N}$ released during $180 \mathrm{~d}$ of incubation for three methylene urea products [Savergy A, Savergy B (Sadepan Chimica, Viadana, Italy), and Cleveland (Cleveland Fertilizer Co., Cleveland, $\mathrm{OH})]$ and two slow-release/ water-soluble fertilizer mixtures [ANSCU (a 25/75 mixture of ammonium nitrate/sulfur-coated urea) and URNT (a 25/75 mixture of urea/ nitroform)] is shown in Table 1 . Ammonium sulfate was also included in the experiment as a standard watersoluble fertilizer control.

A description of the $\mathrm{N}$ release mechanisms for the SRF materials can be found in Sartain and Kruse (2001). Savergy B followed a trend similar to AS, with $95 \%$ of the applied $\mathrm{N}$ released within 28 d. Likewise, Savergy A and Cleveland produced comparable trends in $\mathrm{N}$ release, with Savergy A consistently releasing a larger quantity of $\mathrm{N}$ with time. Cleveland released only about $60 \%$ of the applied $\mathrm{N}$ during the 180 - $\mathrm{d}$ incubation period. N-release curves from the slow-release mixtures did not follow the expected patterns. The ANSCU mixture performed similar to a watersoluble $\mathrm{N}$ material, with $80 \%$ of the applied $\mathrm{N}$ recovered by the first leachate $(7 \mathrm{~d})$. The URNT mixture followed $\mathrm{N}$ release patterns close to a slow-release material with about $88 \%$ of the $\mathrm{N}$ released in $180 \mathrm{~d}$.

\section{Accelerated laboratory extraction methodology}

The nutrient release profile of most commercial SRF materials can be generated by accelerating their natural release mechanism in a laboratory setting. Various increasingly aggressive solvent extraction procedures performed on an unground $30-\mathrm{g}$ sample were used to characterize $\mathrm{N}$ release properties of SRF products. Each extraction was designed to remove and isolate nutrients that release or become available with time. The method included the use of a $0.2 \%$ citric acid extraction solution, four temperatures, and accumulation and combination of extracts. Four extraction sequences were used: 1) $2 \mathrm{~h}$ at $\left.25^{\circ} \mathrm{C}, 2\right) 2 \mathrm{~h}$ at $\left.40^{\circ} \mathrm{C}, 3\right) 20 \mathrm{~h}$ at 50 ${ }^{\circ} \mathrm{C}$, and 4) $50 \mathrm{~h}$ at $60{ }^{\circ} \mathrm{C}$. The extraction apparatus was composed of vertical jacketed chromatography columns enclosing inner columns of $2.5 \times 30 \mathrm{~cm}$ and a water circulation manifold supplied by a centrifugal pump and a water bath capable of maintaining a constant temperature. It also included roll clamps, flow monitors, and two in-line thermometers to accomplish balanced flow and uniform temperature. A 16-channel, reversible peristaltic pump was used to move extraction solutions through the system at a flow rate of $4 \mathrm{~L} \mathrm{~min}^{-1}$. Each column was filled with $475 \mathrm{~mL}$ of extracting solution from the bottom and the solution then circulated throughout the columns for a specific period of time. At the end of each extraction period, the flow was reversed and the sample was collected at the bottom by pumping air into the column from the top. The liquid extracts from each extraction procedure were then analyzed for total $\mathrm{N}$ using the Antek $9000 \mathrm{~N}$ analyzer. The general linear model procedure of SAS (version 9.0; SAS Institute, Cary, NC) was used to statistically analyze the data obtained from both experiments. Treatment means from the lysimeter experiment were compared with Duncan's multiple range test $(\alpha=0.05)$. Figure 1 shows a graphic presentation of data for the five SRF materials tested.

\section{Correlation of soil incubation and accelerated laboratory extraction methodology}

Data generated using the laboratory method can be correlated with the soil incubation method such that the $\mathrm{N}$ release curve with time for a specific SRF product can be predicted based on the accelerated laboratory extraction data. Nonlinear regression techniques are used to establish this relationship. The first step is to fit nonlinear regression curves to the $\mathrm{N}$ release data to establish a functional form of the soil incubation release curve and save the release constants. In the second step, the values of the release constants and the values of the four extractions (E1, E2, E3, and E4) for the accelerated laboratory

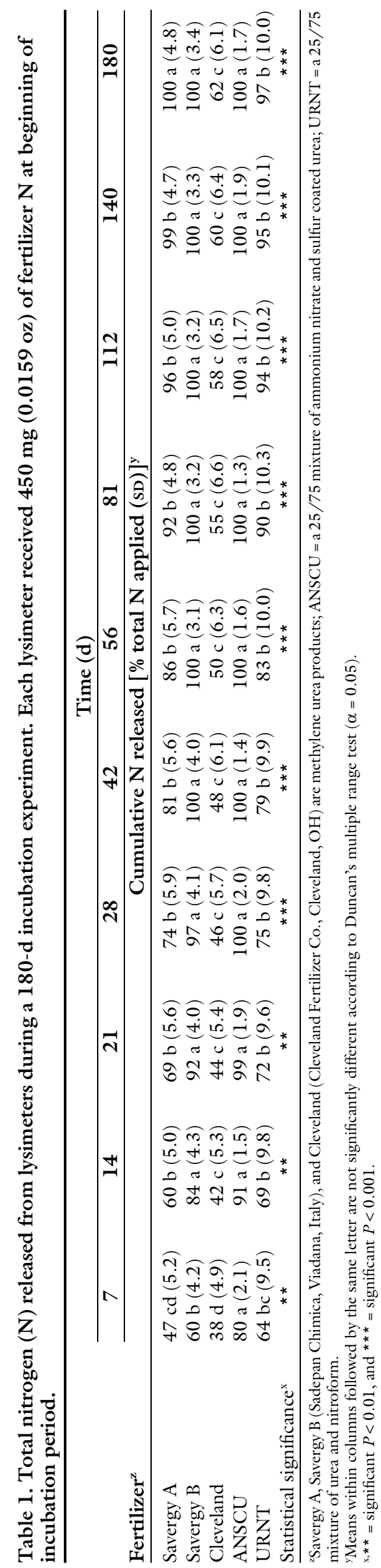




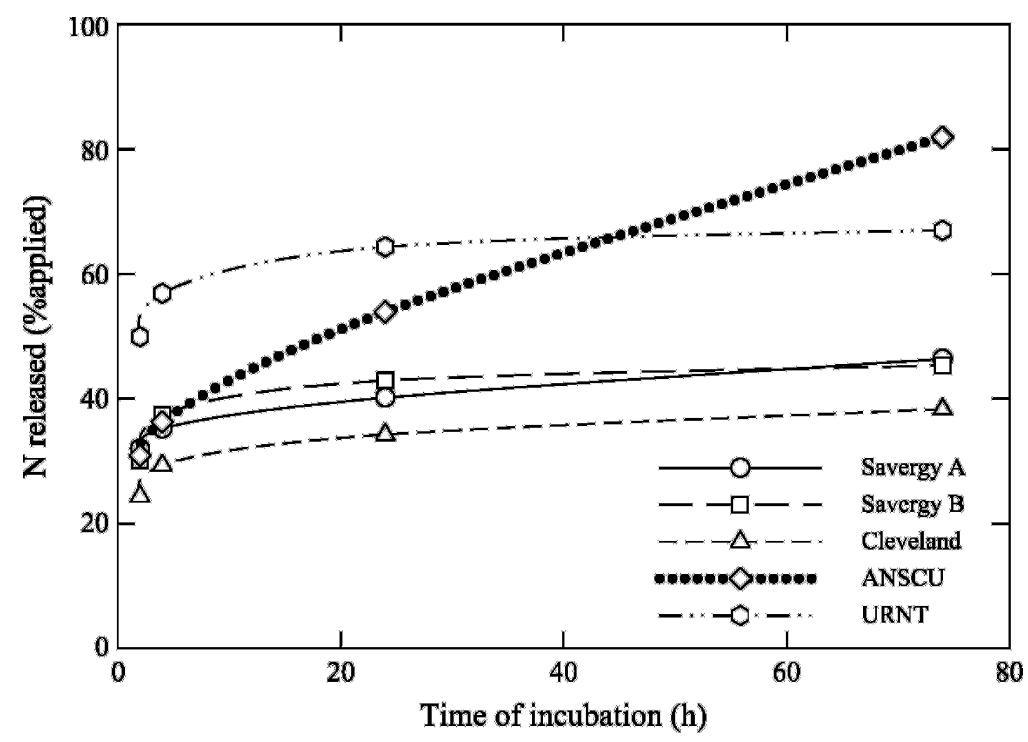

Fig. 1. Nitrogen $(\mathrm{N})$ release curves using the accelerated extraction methodology [ $2 \mathrm{~h}$ at $25^{\circ} \mathrm{C}\left(77.0^{\circ} \mathrm{F}\right) ; 2 \mathrm{~h}$ at $40{ }^{\circ} \mathrm{C}\left(104.0^{\circ} \mathrm{F}\right) ; 20 \mathrm{~h}$ at $50{ }^{\circ} \mathrm{C}\left(122.0{ }^{\circ} \mathrm{F}\right) ;$ and 50 $\mathrm{h}$ at $60^{\circ} \mathrm{C}\left(140.0^{\circ} \mathrm{F}\right)$ ] for three methylene urea products [Savergy A, Savergy B (Sadepan Chimica, Viadana, Italy), and Cleveland (Cleveland Fertilizer Co., Cleveland, $\mathrm{OH}$ ) ] and two slow-release/water soluble mixtures (ANSCU $=$ a 25/75 mixture of ammonium nitrate and sulfur coated urea; URNT = a 25/75 mixture of urea and nitroform).

procedure are used to fit equations of a multiple regression model in which $\mathrm{E} 1, \mathrm{E} 2, \mathrm{E} 3$, and E4 are used as "explanatory" variables and the release constants are "dependent" variables. Then, for a fertilizer material whose $\mathrm{N}$ release curve is desired, values of $\mathrm{E} 1, \mathrm{E} 2, \mathrm{E} 3$, and $\mathrm{E} 4$ are obtained and inserted into the fitted equations to predict the values of the release constants. Finally, the predicted values of the release constants are used to create the estimated $\mathrm{N}$ release curve for a $180-\mathrm{d}$ period. A
SRF label claims and effectiveness. However, it has proven to be more difficult to estimate $\mathrm{N}$ release curves for some types of SRF materials, as well as mixtures of slow release and soluble materials. More data need to be generated using the soil and laboratory methods to establish reproducible equations. The data generated by the soil incubation method represents release of $\mathrm{N}$ tested under agronomic conditions. Therefore, the accelerated laboratory extraction data are being correlated with $\mathrm{N}$ release under reproducible biological conditions mimicking a natural soil environment.

\section{Literature cited}

Sartain, J.B. and J.K. Kruse. 2001. Selected fertilizers used in turfgrass fertilization. Univ. Florida, IFAS, Soil and Water Sci. Dept. Circ. 1262.

Sartain, J.B., W.L. Hall, R.C. Littell, and E.W. Hopwood. 2004a. New tools for the analysis and characterization of slowreleased fertilizers, p. 180-195. In: W.L. Hall and W.P. Robarge (eds.). Environmental impact of fertilizer on soil and water. Amer. Chem. Soc. Symp. Ser. 872. Oxford University Press, Washington, DC.

Sartain, J.B., W.L. Hall, R.C. Littell, and E.W. Hopwood. 2004b. Development of methodologies for characterization of slow-released fertilizers. Soil Crop Sci. Soc. Florida Proc. 63:72-75.

Trenkel, M.E. 1997. Controlled-release and stabilized fertilizers in agriculture. International Fertilizer Industry Assn., Paris. 